\title{
Polymorphisms in $\mathrm{NCF} 4$ and $S A A 2$ Genes and Production and Reproduction Traits of Dairy Cattle
}

\author{
Inga Kowalewska-Luczak ${ }^{1}$ and Ewa Czerniawska-Piątkowska ${ }^{2, *}$ \\ ${ }^{1}$ Department of Genetics and Animal Breeding, Faculty of Biotechnology and \\ Animal Breeding, West Pomeranian University of Technology in Szczecin, Piastów \\ Avenue 45, 79-311 Szczecin, Poland \\ ${ }^{2}$ Department of Ruminant Sciences, Faculty of Biotechnology and Animal Breeding, \\ West Pomeranian University of Technology in Szczecin, Klemensa Janickiego 29, \\ 71-270 Szczecin, Poland
}

\begin{abstract}
A B S T R A C T
The aim of the study was to analyze the possible influence of polymorphism in the NCF4 and SAA2 genes on selected milk and reproductive traits in the Polish Holstein-Friesian cattle (black and white variety). Analysis of genotypes of individual species was carried out using the PCR-RFLP. The frequency of the most occurring alleles for the individual polymorphisms studied was the following g.18174 $\mathrm{A}>\mathrm{G} N C F 4$ gene $A-0.807 ; S A A 2$ c. $-84 \mathrm{G}>\mathrm{C} G-0.777$ and $S A A 2 \mathrm{c} .114 \mathrm{G}>\mathrm{A} G-0.843$. Statistical analysis allowed to show, in the case of $S A A 2$ c. $-84 \mathrm{G}>\mathrm{C}$ polymorphisms, cows with the $C C$ genotype were characterized by the highest content of protein and the lowest content of fat in milk. On the other hand, for the SAA2 c.114G $>$ A polymorphism, it was shown that cows with $G A$ genotype were characterized by the lowest calving interval $(\mathrm{P} \leq 0.05)$. In summary, the information contained in this study may be useful for further analysis to determine the effect of the analyzed polymorphisms in the NCF4 and SAA2 genes on the milk production and reproductive traits of dairy cattle.
\end{abstract}

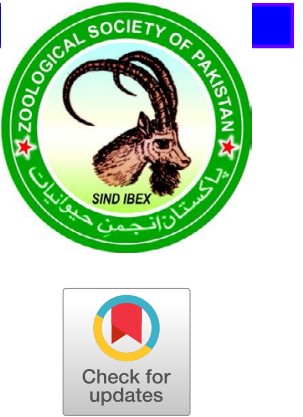

Article Information Received 22 May 2019 Revised 30 July 2019 Accepted 02 September 2019 Available online 11 January 2021

Authors' Contribution IKL and ECP conceived and planned the study. IKL conducted blood sampling and lab work and drafted the manuscript. ECP statistically analyzed the data.

Key words

Dairy cattle, Gene polymorphism, Milk production traits, Reproduction traits.

\section{INTRODUCTION}

$\mathrm{A}$ genomic selection allows for accurate identification of animals of high genetic value at an early age, due to the use of information contained in the DNA for estimating the breeding value. A genomic evaluation allows optimization of the improvement of inherited features, and also allows the improvement of a number of features. In the case of dairy cattle, breeding targets primarily focused mainly on increasing milk production. This led to neglect of other traits, and as a result of a negative correlation with the milk productivity, even a decrease in their value. Holstein-Friesian cows reach increasingly higher results in milk production, which burden their organisms, and this in turn causes that they are used too short, which leads to an increase in the costs of the herd renovation. It is influenced by a number of factors including problems with milking or an udder disease (Rehak et al., 2012).

Due to the biological functions of proteins encoded by the NCF4 (neutrophil cytosolic factor 4) and $S A A 2$

\footnotetext{
Corresponding author: ewa.czerniawska-piatkowska@ zut.edu.pl 0030-9923/2021/0002-0453 \$ 9.00/0

Copyright 2021 Zoological Society of Pakistan
}

(serum amyloid A2) genes, these genes have been proposed as potential DNA markers for resistance to mastitis (Ju et al., 2015; Yang et al., 2015). Since the health condition, production and reproduction efficiency are among the most important parameters in dairy cattle and are related to each other, it is also worth analyzing whether the NCF4 and $S A A 2$ genes can also be potential DNA markers for production and reproductive efficiency.

The NCF4 gene is an important gene coding for one of the subunits (p40-phox) of NADPH oxidase that is directly involved in cellular respiratory processes (Gustafson et al., 2014). This multi-subunit structure plays a major role in defense mechanisms against microbial invasion. It has been shown that during the bacterial infection, this complex is translocated in the phagocytic cell membrane, where reactive oxygen species are produced and the bacteria are controlled (Zhan et al., 2004). Mastitis is an inflammatory disease caused by various pathogenic microorganisms of dairy cattle, and the NCF4 gene appears to be a significant gene of innate immunity, playing an important role in mastitis in cattle (Ju et al., 2015).

Serum amyloid A is a lipoprotein that is found in plasma. Together with high density lipoprotein, it forms a complex as apolipoprotein and plays a role in the repair of damaged tissue as a result of an inflammatory 
reaction. The SAA protein owes its name to its function as a precursor of serum secondary amyloid plaques that are deposited in the main organs of the body as a result of chronic inflammatory diseases (Sun and Ye, 2016). Veterinary research has shown that the measurement of SAA protein concentration can be used to facilitate the diagnosis of inflammation or to monitor the response to the treatment of inflammation (Eckersall and Bell, 2010). Serum amyloid A can be used as an indicator of inflammation in ruminant animals (Hussein et al., 2018). The usefulness of SAA level determination results from rapid and exponential growth during the course of an inflammatory disease (Nazifi et al., 2008).

The present study was aimed at conducting an analysis between genetic variants of polymorphisms g.18174 A $>\mathrm{G}$ in the NCF4 gene and c. $-84 \mathrm{G}>\mathrm{C}$ and c. $114 \mathrm{G}>\mathrm{A}$ in the $S A A 2$ gene in relation to selected traits of milk yield and selected parameters of bovine reproduction.

\section{MATERIALS AND METHODS}

\section{Animals and phenotype}

The study involved a herd of 150 Polish HolsteinFriesian black-and-white cows. The herd was kept in north-western Poland. Test subjects were at similar age and at different stages of lactation. The animals were fed normalized dietary doses, with the possibility of using pastures in the spring and summer. Each cow from the tested herd had documented milk production. The milking was carried out twice a day. Testing milks were made according to the A4 method. The A4 method is a reference method for assessing the milk yield of cows in Poland accepted by the International Organization of ICAR. This method is implemented by carrying out 11 to 13 trials of milking per year (on average every month), and the measurement of the amount of milk is carried out in each milking throughout the day.

\section{DNA extraction and genotypes}

To extract DNA, peripheral blood was collected from the external jugular vein, which was collected from each subject. Peripheral blood was collected into vacuum tubes containing $\mathrm{K}_{3}$ EDTA as an-coagulant. DNA isolation was performed using the MasterPure Kit (Epicenter Technologies). The insulation took place in conditions consistent with the recommendations from the manufacturer. After complete isolation, the purified DNA was suspended in TE buffer and then stored at $4^{\circ} \mathrm{C}$.

PCR in combination with RFLP was used to determine the genotypes of each individual from the tested cow herd. A single nucleotide polymorphism (SNP) was analyzed in the intron 9 of the gene encoding the p40-phox protein, which is part of the NADPH oxidase, the analyzed SNP is the change g.18174 $\mathrm{A}>\mathrm{G}$ (rs464505021). Subsequent polymorphisms (also SNP) investigated were located in the promoter of the gene encoding serum amyloid A2. These were the conversion of guanine to cytosine at position -84 (rs110148509) and guanine to adenine at position 114 (rs 210440016). Primer sequences, sizes of the amplified fragments in PCR, annealing temperature and restriction enzymes are shown in Table I. The products obtained were digested with the appropriate restriction enzymes and the obtained restriction fragments were separated in $2 \%$ agarose gels.

\section{Association analysis}

Genotyping results were subjected to statistical analysis - the frequency of occurrence of genotypes and alleles for individual polymorphisms was calculated using the PopGene version 1.32 (Yeh et al., 1999) and it was checked whether the distribution of alleles of the tested genes was consistent with the Hardy-Weinberg equilibrium. An $\chi^{2}$ test was also used to check the compliance of the observed and expected prevalence of genotypes. To assess the genetic diversity in the examined herd of cattle, parameters such as the degree of heterozygosity (heterozygosity expected) and the polymorphic information content (PIC) were used (Botstein et al., 1980; Ott, 1985). Later, the dependencies between genotypes and milk production traits and functional traits such as daily milk yield, protein and fat content, number of somatic cells, age of first calving, interpregnancy period and calving interval were analyzed. Statistical analysis of the relationship between the polymorphisms studied in the

Table I.- Primer sequences, sizes of the amplified fragments in PCR and restriction enzymes.

\begin{tabular}{|c|c|c|c|c|}
\hline SNP & Primer sequence $\left(5^{\prime}-3^{\prime}\right)$ & AT & $\mathbf{A S}$ & $\mathbf{R E}$ \\
\hline \multirow[t]{2}{*}{ NCF4 g.18174A $>\mathrm{G}$} & F: 5'CCAGCTCTGACCCCTTCCAATTC3' & $53^{\circ} \mathrm{C}$ & $178 \mathrm{bp}$ & AvaII \\
\hline & R: 5'CCCCCTCAGCGTCACGGTAG3' & & & \\
\hline$S A A 2$ c. $-84 \mathrm{G}>\mathrm{C}$ & F: 5'AAACGCATGGCTGAGAGACT3' & $60^{\circ} \mathrm{C}$ & 516 bp & HinfI \\
\hline$S A A 2$ c. $114 \mathrm{G}>\mathrm{A}$ & R: 5' GACAGGGGTGAGGAGAACAG3' & & & AvaII \\
\hline
\end{tabular}

AT, annealing temperature; AS, amplicon size; RE, restriction enzyme. 
NCF4 and SAA2 genes and the milk production traits and selected reproductive parameters were performed using the Statistica 12PL program (StatSoft, Poland 2012). Mean values and standard deviation were calculated and a one-way analysis of variance was carried out using the Duncan multiple range test.

Linear model: $\mathrm{Y}_{\mathrm{ikj}}=\mu+\mathrm{N}_{\mathrm{i}}+\mathrm{S}_{\mathrm{j}}+\mathrm{L}_{\mathrm{j}}+\mathrm{e}_{\mathrm{ijk}}$ where, $Y_{i j}$ is analyzed variable (daily milk yield, fat content in milk, protein content in milk, number of somatic cells, age at first calving, interpregnancy period, calving interval). $\mu$ is expected value, $\mathrm{N}_{\mathrm{i}}$ is the effect of genotype $N C F 4$ g. $18174 A>G$, i is $A A, A G$ and $G G, \mathrm{~S}_{\mathrm{j}}$ is the effect of genotype $S A A 2$ c. $-84 G>C$, j is $G G, G C$ and $C C, \mathrm{~L}_{\mathrm{j}}$ is the effect of genotype $S A A 2$ c. $114 G>A, \mathrm{j}$ is $G G, G A$ and $A A$, and $\mathrm{e}_{\mathrm{ijk}}$ is random error.

\section{RESULTS}

As a result of the digestion of the obtained products with the appropriate enzymes, the following alleles were identified: for SNP in NCF4 gene - $A$ allele (178 bp) and $G$ allele $(92,86 \mathrm{bp})$, for polymorphism $S A A 2$ gene c.- $84 \mathrm{G}>\mathrm{C}$
$G$ allele $(228,176,112$ bp) and $C$ allele $(228,176,80,32$ $\mathrm{bp)}$ and for polymorphism $S A A 2$ gene c. $114 \mathrm{G}>\mathrm{A} G$ allele (432, 43, $41 \mathrm{bp}$ ) and $A$ allele $(473,43 \mathrm{bp})$. The calculated frequency of particular alleles and genotypes has been shown in Table II.

The calculated value of $\chi^{2}$ for two analyzed polymorphisms is greater than the critical value, which may be the result of long-term selection towards production traits in in Holstein-Friesian cattle. Low values of heterozygosity may be an effect of inbreeding and conducted selection in the studied stock, which is why this information may be useful during further breeding of dairy cattle. The PIC classification according to Botstein et al. (1980) indicates a low, medium and high polymorphism, respectively, the value of $\mathrm{PIC}<0.25$ is low polymorphism; $0.25<\mathrm{PIC}$ value $<0.5$ is average polymorphism and $\mathrm{PIC}>$ 0.5 is high polymorphism. According to this classification, one has shown low and medium levels of polymorphic information for the analyzed polymorphisms in the studied herd of cattle on the basis of expected heterozygosity.

Table III presents the results of statistical analysis related to the daily milk yield, protein and fat content, and the number of somatic cells in the examined herd of cows.

Table II.- Frequencies of alleles and genotypes of studied polymorphisms.

\begin{tabular}{|c|c|c|c|c|c|c|c|}
\hline SNP & Genotype & Frequency & Allele & Frequency & $\chi^{2}$ & $\mathbf{H}_{\mathrm{e}}$ & PIC \\
\hline NCF4 & $A A$ & 0.687 & $\mathrm{~A}$ & 0.807 & $7.97^{*}$ & 0.31 & 0.260 \\
\hline \multirow{2}{*}{ g. $18174 \mathrm{~A}>\mathrm{G}$} & $A G$ & 0.240 & $\mathrm{G}$ & 0.193 & & & \\
\hline & $G G$ & 0.073 & & & & & \\
\hline SAA2 & $G G$ & 0.620 & $\mathrm{G}$ & 0.777 & 1.4 & 0.35 & 0.284 \\
\hline \multirow[t]{2}{*}{ c. $-84 \mathrm{G}>\mathrm{C}$} & $G C$ & 0.313 & $\mathrm{C}$ & 0.223 & & & \\
\hline & $C C$ & 0.067 & & & & & \\
\hline SAA2 & $G G$ & 0.773 & $\mathrm{G}$ & 0.843 & $33.16^{* * *}$ & 0.26 & 0.233 \\
\hline \multirow[t]{2}{*}{ c. $114 \mathrm{G}>\mathrm{A}$} & $G A$ & 0.140 & A & 0.157 & & & \\
\hline & $A A$ & 0.087 & & & & & \\
\hline
\end{tabular}

$\chi^{2}$, Hardy-Weinberg equilibrium $\chi^{2}$ value; $\mathrm{H}_{\mathrm{e}}$, gene heterozygosity; $\mathrm{PIC}$, polymorphism information content; $* * *, \mathrm{P}<0.001 ; *, \mathrm{P}<0.05$.

Table III.- Mean values and standard deviation for milk production traits.

\begin{tabular}{lcccccc}
\hline SNP & Genotype & n & Milk (kg) & Protein (\%) & Fat (\%) & SCS \\
\hline NCF4 & $A A$ & 103 & $15.12 \pm 1.52$ & $3.32 \pm 0.18$ & $3.92 \pm 0.50$ & $3.12 \pm 1.02$ \\
g.18174 A $>$ G & AG & 36 & $15.27 \pm 1.44$ & $3.28 \pm 0.19$ & $3.90 \pm 0.52$ & $3.13 \pm 1.26$ \\
& GG & 11 & $15.22 \pm 1.18$ & $3.35 \pm 0.19$ & $3.87 \pm 0.50$ & $3.24 \pm 1.10$ \\
SAA2 & $G G$ & 93 & $15.12 \pm 1.47$ & $3.99 \pm 0.48^{\mathrm{a}}$ & $3.34 \pm 0.18^{\mathrm{A}}$ & $3.21 \pm 1.18$ \\
c.-84 G>C & GC & 47 & $15.10 \pm 1.37$ & $3.81 \pm 0.50$ & $3.29 \pm 0.18^{\mathrm{a}}$ & $3.05 \pm 0.90$ \\
& CC & 10 & $15.80 \pm 1.88$ & $3.62 \pm 0.52^{\mathrm{a}}$ & $3.17 \pm 0.10^{\mathrm{Aa}}$ & $2.79 \pm 0.85$ \\
SAA2 & $G G$ & 116 & $15.14 \pm 1.52$ & $3.94 \pm 0.51$ & $3.32 \pm 0.19$ & $3.19 \pm 1.15$ \\
c.114G $>$ A & GA & 21 & $15.36 \pm 1.46$ & $3.93 \pm 0.47$ & $3.32 \pm 0.13$ & $2.82 \pm 0.75$ \\
& AA & 13 & $15.02 \pm 1.02$ & $3.67 \pm 0.40$ & $3.25 \pm 0.13$ & $3.18 \pm 0.74$ \\
\hline
\end{tabular}

Mean values in rows marked with the same case letters differ significantly at: ${ }^{a} \mathrm{P} \leq 0.05 ;{ }^{\mathrm{A}} \mathrm{P} \leq 0.01$. 
Table IV.- Mean values and standard deviation for reproduction traits.

\begin{tabular}{lccccc}
\hline SNP & Genotype & $\mathbf{n}$ & Age at first calving (days) & Interpregnancy period (days) & Calving interval (days) \\
\hline NCF4 & $A A$ & 103 & $847.05 \pm 97.23$ & $145.38 \pm 60.94$ & $470.29 \pm 82.92$ \\
g.18174 A>G & AG & 36 & $859.42 \pm 96.37$ & $159.35 \pm 64.06$ & $451.56 \pm 65.66$ \\
& GG & 11 & $851.18 \pm 96.01$ & $186.00 \pm 97.70$ & $486.71 \pm 72.07$ \\
SAA2 & $G G$ & 93 & $867.24 \pm 101.77$ & $151.75 \pm 59.43$ & $459.98 \pm 70.45$ \\
c.-84 G>C & GC & 47 & $827.45 \pm 80.73$ & $155.46 \pm 82.55$ & $495.00 \pm 77.26$ \\
& GC & 10 & $800.40 \pm 79.49$ & $151.29 \pm 44.98$ & $405.14 \pm 108.24$ \\
SAA2 & $G G$ & 116 & $852.91 \pm 98.06$ & $145.76 \pm 58.76$ & $470.62 \pm 76.55$ \\
c.114G $>$ A & GA & 21 & $840.57 \pm 101.70$ & $149.50 \pm 54.36$ & $448.07 \pm 83.73^{\mathrm{a}}$ \\
& AA & 13 & $842.92 \pm 76.14$ & $200.22 \pm 101.51$ & $481.17 \pm 102.65^{\mathrm{a}}$ \\
\hline
\end{tabular}

Mean values in rows marked with the same case letters differ significantly at: ${ }^{a} \mathrm{P} \leq 0.05$.

Analysis of the results obtained for polymorphism g.18174 A $>\mathrm{G}$ in the NCF4 gene did not show statistically significant differences between individual genotypes in relation to selected milk production traits. But some tendencies were observed: it was observed that individuals with the $A A$ genotype were characterized by the lowest daily milk yield, cows with a heterozygous genotype produced milk with the lowest protein content, and cows with the $G G$ genotype were characterized by the lowest milk fat content and the highest number of somatic cells in milk.

For $S A A 2$ c. $-84 \mathrm{G}>\mathrm{C}$ polymorphisms, statistically significant differences were found during the analysis in the case of features such as protein content and fat in milk. It was found that cow's milk with the $C C$ genotype was characterized by a significantly $(\mathrm{P} \leq 0.05)$ lower protein content in reference to milk from cows with the genotype $G G$. However, in the case of fat content in milk, it was found that individuals with the $C C$ genotype were characterized by a statistically significant lower fat content than cows with the genotype $G G(\mathrm{P} \leq 0.01)$ and $G C(\mathrm{P} \leq$ $0.05)$. For the other analyzed milk-related traits in relation to individual $S A A 2$ c. $-84 \mathrm{G}>\mathrm{C}$ genotypes, it was shown that individuals with the $C C$ genotype were characterized by the highest daily milk yield and the lowest somatic cell count.

In the case of $S A A 2 \mathrm{c} .114 \mathrm{G}>\mathrm{A}$ polymorphism, it was found that cows with genotype $G A$ were characterized by the highest daily milk yield and the lowest somatic cell count, and animals with $A A$ genotype were characterized by the lowest content of protein and fat in milk, however, these differences were not statistically significant.

Table IV presents selected characteristics of reproductive traits, such as the age of the first calving, the interpregnancy period and the calving interval.

The analysis of the data presented in Table IV allows to state that in the case of polymorphism in the NCF4 gene, the $A A$ genotype cows were characterized by the lowest age of the first calving and the shortest interpregnancy period, while heterozygous cows were characterized by the shortest calving interval. However, these differences have not been statistically confirmed.

For $S A A 2$ c. $-84 \mathrm{G}>\mathrm{C}$ polymorphisms, it was observed that cows with the $G G$ genotype were characterized by the highest age of the first calving, while the individual with the $C C$ genotype was the shortest calving interval. On the other hand, in the case of $S A A 2$ c. $114 \mathrm{G}>\mathrm{A}$ polymorphism, it was observed that cows with the $G G$ genotype were characterized by the longest age of the first calving, the $A A$ genotype cows with the longest interpregnancy period, and heterozygous cows characterized by the shortest intercalving period, with the difference between animals with $G A$ and $A A$ genotypes statistically confirmed $(\mathrm{P} \leq$ $0.05)$.

\section{DISCUSSION}

In recent years, breeders are particularly interested in functional features important due to the system of animal maintenance and mechanization of breeding, and above all the economy of production. Features such as fertility and health of udder are increasingly important in the management of the herd. This is reflected in breeding programs (selection programs) in which more emphasis is put on improving these functional features, with particular regard on polymorphisms in genes candidate for QTL affecting the traits such as $G H$ or Pit-1 genes (Amiri et al. 2018). The genes examined in the above study were also the subject of research by other authors, albeit by few of them. Thus, the same polymorphism (g.18174 A>G) in the NCF4 gene has been studied so far only by Ju et al. (2015) in the herd of Holstein Chinese cattle, where the frequency of the $A$ allele was demonstrated at 0.67 , which is slightly lower than in the own research. In the case of 
polymorphisms in the $S A A 2$ gene in the work of Yang et al. (2015) in the Holstein Chinese cattle herd was shown the frequency of the most common alleles similar for $S A A 2$ c.$84 \mathrm{G}>\mathrm{C}(\mathrm{G} 0.72)$ or slightly lower for $S A A 2$ c. $114 \mathrm{G}>\mathrm{A}(\mathrm{G}$ 0.742 ) than in the above study.

The milk production traits have so far not been analyzed in relation to polymorphism g.18174 A $>\mathrm{G}$ in the NCF4 gene, only the somatic cells in milk (Ju et al., 2015) have been focused on, where statistically significant effect $(\mathrm{P} \leq 0.05)$ from SCS has been demonstrated and, as the authors claim, this polymorphism may contribute to the improvement of mastitis resistance. Polymorphisms in the $S A A 2$ gene in relation to the characteristics of milk yield were analyzed in the work of Yang et al. (2015), where it was shown that the $S A A 2$ gene polymorphisms c.-84 G>C and c. $114 \mathrm{G}>\mathrm{A}$ are significantly related to the estimated breeding value (EBV) for traits such as milk yield and protein yield in milk. In the case of $S A A 2$ c.114 G>A polymorphism, this effect is explained by the location of this polymorphism in the promoter part, and thus by the possible effect on the change of the gene's transcriptional activity. In the conducted study, although based on daily productivity data, a significant effect on milk protein $(\mathrm{P} \leq$ $0.05)$ and fat content $(\mathrm{P} \leq 0.05, \mathrm{P} \leq 0.05)$ was demonstrated for c. $-84 \mathrm{G}>\mathrm{C}$ polymorphisms.

Disorders in reproduction are the cause of the greatest losses in dairy farms, and due to fertility problems farmers are incurring additional costs, including related to veterinary service, and record losses resulting, for example, from reduced productivity. The genetic correlations between milk and fertility are negative. Fertility decreases with increasing genetic value for milk (Windig et al., 2006). This means that selection for increased milk yields a decrease in fertility and vice versa - selection for fertility reduces milk yield. Therefore, the comprehensive assessment of dairy cattle should include, in addition to milk yield, functional traits that describe the parameters of reproduction. For this reason, the above study decided to analyze selected traits such as the age of the first calving, the interpregnancy period and the calving interval for polymorphisms in the NCF4 and SAA2 genes, especially since this aspect has not appeared in the studies so far.

In the case of polymorphism in the NCF4 gene, it was observed that milk obtained from cows of the lowest age of the first calving and the shortest calving interval was characterized by the lowest number of somatic cells (AA genotype), while the cows with the shortest calving interval were characterized by the highest daily milk yield ( $A G$ genotype). For $S A A 2$ c-84 $\mathrm{G}>\mathrm{C}$ polymorphism, it was observed that the cows with the lowest age of the first calving and the shortest calving interval were characterized by the highest daily milk yield with the lowest number of somatic cells, with the lowest values for protein and fat (CC genotype). However, in the case of $S A A 2$ c.114G $>\mathrm{A}$ polymorphism, it can be noticed that the cows had the shortest daily milk yield and the lowest somatic cell count ( $G A$ genotype), while the milk obtained from the animals with the longest interpregnancy period was characterized by the lowest protein and fat content.

The improvement of functional features is difficult due to the low heritability of these traits. An additional problem is the negative genetic correlation between these traits and milk yield (Castillo-Juarez et al., 2000). The inter-calving period is often used as a measure of fertility, because the gap between calves indicates the final effect of effective calving. The calving interval allows us to analyze the fertility assessment of cows kept in commercial dairy farms and has been used in several studies in which the genetic basis of fertility was estimated and its relation to other commonly registered production traits (AlbarránPortillo and Pollott, 2013).

\section{CONCLUSION}

Functional features are a group of non-productive features that indirectly affect the overall effectiveness of milk production in a herd of cows and neglecting the improvement of these features may cause the occurrence of premature shortage of animals from the herd for a variety of reasons related to low fertility or health problems. The conducted research is an attempt to find a balance between achieving the desired production effects while caring for functional features. As a result of the conducted research, it was possible to show a statistically significant effect $(\mathrm{P}$ $\leq 0.05$ and $\mathrm{P} \leq 0.01$ ) of the c. $-84 \mathrm{G}>\mathrm{C}$ polymorphism in $S A A 2$ gene on the content of protein and fat in milk as well as the effect $(\mathrm{P} \leq 0.05)$ of the c. $114 \mathrm{G}>\mathrm{A}$ polymorphism on the length of the calving interval.

\section{CONCLUSION}

In conclusion, according to the results presented, it seems that the work may bring a new look at the influence of polymorphisms in the NCF4 and SAA2 genes on traits such as milking or fertility from an economic point of view.

\section{Statement of conflict of interest}

Authors have declared no conflict of interest.

\section{REFERENCES}

Albarrán-Portillo, B. and Pollott, G.E., 2013. The relationship between fertility and lactation 
characteristics in Holstein cows on United Kingdom commercial dairy farms. J. Dairy Sci., 96: 635-646. https://doi.org/10.3168/jds.2012-5632

Amiri, S., Jemmali, B., Ferchichi, M.A., Jeljeli, H., Boulbaba, R. and Gara, A.B., 2018. Assessment of growth hormone gene polymorphism effects on reproductive traits in Holstein dairy cattle in Tunisia. Arch. Anim. Breed., 61: 481-489. https:// doi.org/10.5194/aab-61-481-2018

Botstein, D., White, E.L., Skolnick, M. and Dawis, R.W., 1980. Construction of a genetic linkage map in man using restriction fragment length polymorphism. Am. J. Hum. Genet., 32: 314-331.

Castillo-Juarez, H., Oltenacu, P.A., Blake, R.W. and Mcculloch, C.E., 2000. Effect of herd environment on the genetic and phenotypic relationships among milk yield, conception rate, and somatic cell score in Holstein cattle. J. Dairy Sci., 83: 807-814. https:// doi.org/10.3168/jds.S0022-0302(00)74943-5

Eckersall, P.D. and Bell, R., 2010. Acute phase proteins: biomarkers of infection and inflammation in veterinary medicine. Vet. J., 185: 23-27. https://doi. org/10.1016/j.tvj1.2010.04.009

Gustafson, H.L., Yao, S., Goldman, B.H., Lee, K., Spier, C.M., LeBlanc, M.L., Rimsza, L.M., Cerhan, J.R., Habermann, T.M., Link, B.K., Maurer M.J., Slager S.L., Persky, D.O., Miller, T.P., Fisher, R.I., Ambrosone, C.B. and Briehl, M.M., 2014. Genetic polymorphisms in oxidative stress related genes are associated with outcomes following treatment for aggressive $\mathrm{B}$ cell non-Hodgkin lymphoma. Am. J. Hematol., 89: 639-645. https://doi.org/10.1002/ ajh.23709

Hussein, H.A., Abd El-Razik, K.A., Gomaa, A.M., Elbayoumy, M.K., Abdelrahman, K.A. and Hosein, H.I., 2018. Milk amyloid A as a biomarker for diagnosis of subclinical mastitis in cattle. Vet. World, 11: 34-41. https://doi.org/10.14202/ vetworld.2018.34-41

Ju, Z., Changfa, W., Xiuge, W., Chunhong, Y., Yan, S., Qiang, J., Fei, W., Mengjiao, L., Jifeng, Z. and Jinming, H., 2015. Role of an SNP in alternative splicing of bovine NCF4 and mastitis susceptibility. PLoS One, 10: e0143705. https://doi.org/10.1371/ journal.pone. 0143705

Nazifi, S., Khoshvaghti, A. and Gheisari, H.R., 2008. Evaluation of serum and milk amyloid A in some inflammatory diseases of cattle. Iranian J. Vet. Res., 9: 222-226.

Ott, J., 1985. Analysis of human genetic linkage. John Hopkins University Press, Baltimore and London.

Rehak, D., Volek, J., Barton, L., Vodkova, Z., Kubesova, M. and Rajmon, R., 2012. Relationships among milk yield, body weight, and reproduction in Holstein and Czech Fleckvieh cows. Czech J. Anim. Sci., 57: 274-282. https://doi.org/10.17221/5962-CJAS

StatSoft, 2012. Statistica, Data Analysis Software System, version 12.0. Poland.

Sun, L. and Ye, R.D., 2016. Serum amyloid A1: Structure, function and gene polymorphism. Gene, 583: 4857. https://doi.org/10.1016/j.gene.2016.02.044

Windig, J.J., Calus, M.P.L., Beerda, B. and Veerkamp, R.F., 2006. Genetic correlations between milk production and health and fertility depending on herd environment. J. Dairy Sci., 89: 1765-1775. https://doi.org/10.3168/jds.S0022-0302(06)722457

Yang, S., Li, C., Xie, Y., Cui, X., Li, X., Wei, J., Zhang, Y., Yu, Y., Wang, Y, Zhang, S., Zang, Q. and Sun, D., 2015. Detection of functional polymorphisms influencing the promoter activity of the $S A A 2$ gene and their association with milk production traits in Chinese Holstein cows. Anim. Genet., 46: 591-598. https://doi.org/10.1111/age.12332

Yeh, F.C., Yang, R.C. and Boyle, T., 1999. POPGENE, Microsoft Window-Based Freeware for population genetic analysis, Version 1.31. University of Alberta and Centre for International Forestry Research, Edmonton, Canada.

Zhan, Y., He, D., Newburger, P.E. and Zhou, G.W., 2004. p47phox PX domain of NADPH oxidase targets cell membrane via moesin-mediated association with the actin cytoskeleton. J. cell. Biochem., 92: 795-809. https://doi.org/10.1002/jcb.20084 